\title{
Electronic Money and Regulatory Responses
}

\author{
Stephen Rimmer and Ravi Prasad
}

$\mathbf{R}$ APIDLY evolving technologies are leading to innovations in banking and in the way goods and services are traded. Many of these changes can be attributed to developments in global communication systems which have accelerated the integration of world markets. Australian consumers with access to a computer linked to the Internet can now purchase compact disks from the United States, gamble at casinos based in the Caribbean, and sell copyrighted publications electronically. As well, new payment systems based on electronic money have proliferated, creating scope for private institutions to issue electronic currency in competition with currencies issued by governments (Kirchner, 1996).

The regulatory responses of governments to this challenge will help determine whether the social and economic benefits available from the emergence of electronic money and commerce can be realised.

\section{Forms of Electronic Money}

Methods of exchange of money are still evolving through the use of technology to include smart cards, such as stored value cards (SVCs). The potential world market for SVCs for purchases under US $\$ 10$ was estimated to be in excess of $300 \mathrm{~m}$ cards in 1995 (Lindley, 1996:2). In addition, a range of Internet-based electronic money or digital currency (e-cash) systems using conventional currency are being developed. The Mondex system, for example, can be traded independently of the banking system. Unlike with the more common SVCs, Mondex users can transfer electronic cash amongst themselves through an electronic wallet. Mondex also allows funds to be transferred through the Internet, in the form of one of five different currencies. The Electronic Money System, like Mondex, can work on a computer network, and allows secure and immediate transfers of cash. Unlike Mondex, it will be able to handle any number of foreign currencies, exchanging them at agreed rates. Netcash uses e-mail to transfer money from one person to another. In contrast, the First Virtual e-cash system requires both parties to a transaction to have accounts at the 'bank', and First Virtual must be able to make charges against the account of the purchaser (Levy, 1995).

Stephen Rimmer is a Director, and Ravi Prasad an economist, at the Office of Regulation Review (ORR), which is part of the Industry Commission. The views expressed here are those of the authors and not necessarily those of the ORR or the Industry Commission. 
E-cash can also take the form of privately issued currencies where conventional currency is used to purchase transferable e-cash, like tokens at an amusement park. Companies like Digicash and Cybercash are developing 'virtual' currencies which operate independently of, and in competition with, conventional currencies. According to Goldschlager and Harper (1996), Digicash is the closest approximation to a virtual currency payments system on the Internet. The currency is a series of digitally signed coins that can be transferred between persons. The consumer can withdraw digital coins from an Internet bank account and store them on a personal computer or vice versa. A web browser provides the interface for displaying account information, transferring digital coins between bank accounts and virtual wallets and confirming or rejecting payment requests. Digicash's security systems are based heavily on cryptography and on the efficacy of digitally signed coins (Levy, 1996:4).

As The Economist (26 November 1994) has put it,

Electronic money of this type could be created in any denomination ... all it presumes is a willing buyer and a willing seller, anyone with a computer and a telephone line can become a small business; forget the hassle and expense of being approved as a credit-card-accepting merchant. . .

\section{The Impact of E-cash}

If e-cash is to be accepted by consumers as a viable alternative to paper cash, it will have to be secure, anonymous, portable, transferable, off-line capable (parties must be able to transfer funds at any time without the need for a third party to authenticate transactions), divisible, of infinite duration, widely acceptable, easy to use, readily convertible, versatile, cheap, and trustworthy. True virtual cash systems will be denominated in market determined units, which are not aligned to any national currency. However, the assets backing them will help give them value, allowing convertibility into conventional currency. ${ }^{1}$

In theory, anyone could provide a monetary unit, which could then be exchanged for goods and ultimately even for conventional currencies. If these new monetary units are backed by something of value and there is considerable customer confidence in them, they could even be endogenously generated, and traded for conventional currency at market determined exchange rates.

E-cash also represents a fundamental shift in payment methods because it has the potential to transfer funds instantaneously, by means which are often difficult for governments to monitor or regulate. It is this electronic exchange medium which could provide the basis for the return of free banking, whereby private organisations - or indeed State or local governments - could issue their own forms of electronic currency.

\footnotetext{
1 Goldschlager and Harper (1996:3) envisage that e-cash could be backed up by a multitude of goods including equity mutual funds, commodity funds, metals, real estate and other forms of digital cash.
} 
E-cash raises a number of important regulatory issues and dilemmas. It could allow consumers to choose between different currencies, providing additional incentives for governments to control inflation to ensure public confidence in government-issued currency. It could result in a loss of revenues from tax avoidance and the loss of income earned by central banks through investment of the proceeds of note issues (seigniorage). ${ }^{2}$ It also raises important questions regarding the control of money laundering and consumer protection. Privacy is also likely to become a important issue for governments. Further, in theory the widespread use of e-cash and real time (immediate) gross settlement could render government-issued media of exchange obsolete.

The overall impact of e-cash will also depend on the pace and direction of technological change and the response to this by consumers, businesses and governments. For example, public key cryptography and encrypted data communication is essential for the effective functioning of electronic commerce. Many Western governments consider encryption technology to be a military secret. In some countries, such as France, its use is prohibited. However, advanced encryption programs, such as Pretty Good Privacy, which are difficult to decode even with the aid of super computers, are currently freely available over the Internet. Such programs allow for relatively secure communication over the Internet. However, notwithstanding the potential benefits of e-cash, it should be borne in mind that consumers often eschew the use of new technology (Levy, 1996).

\section{International Regulatory Responses to E-cash}

Currently, more than ten major international reviews of e-cash are under way (Electronic Commerce Task Force, 1996:136-9). For example, the Asia Pacific Economic Cooperation Forum Ministers for Communications have jointly agreed to promote electronic commerce through the Internet, which will require greater regulatory compatibility between countries (Australian Financial Review, 9 October 1996). The Society for Worldwide Interbank Financial Telecommunications has established common technical standards for international financial transactions (Financial Systems Inquiry, 1996:293, 300). The Bank for International Settlements (1996) is closely monitoring technological and regulatory developments impacting on electronic money. Some international reviews have a more specific focus, such as assessing the impact on particular areas or groups. For example, the International Organisation of Securities Commissions has established a working group to assess consumer protection issues. The Organisation for Economic Cooperation and Development (OECD) is currently developing guidelines for a global Internet tax (Australian Financial Review, 4 March 1997).

Many individual countries are undertaking research and seeking to institute regulatory regimes for future innovations in Internet technologies. For example, a task force established by US President Clinton to investigate e-cash has released a

\footnotetext{
2 In Australia, the annual value of seigniorage was equal to between 1.5 and 3.5 per cent of total Commonwealth outlays in the 1980s and early 1990s (Harper \& Leslie, 1996:26).
} 
draft report titled 'A Framework for Global Electronic Commerce' which covers nine key issues, from taxation to customs and privacy. In particular, it has recommended that no new taxes be imposed on Internet commerce (Australian Financial Review, 9 December 1996). The Vice-Chairman of the US Federal Reserve Bank, Alan Blinder (1995), has stated that 'the Federal Reserve has not the slightest desire to inhibit the evolution of this emerging industry by regulation, nor to constrain its growth. ... [T] [Te Board ... will continue to encourage innovations in payments technologies that benefit consumers and businesses'. He has called on US regulators to avoid impeding introduction of electronic commerce.

While governments and international agencies broadly accept the likely growth in e-cash, they are uncertain how to design appropriate regulatory responses, and are generally adopting a wait-and-see approach to the growth of electronic commerce.

\section{Australian Regulatory Responses to E-cash}

Australia's regulatory response to e-cash comprises over 20 domestic reviews of electronic commerce. In addition, several regulators are currently investigating the likely impact of e-cash on particular sectors of the economy and on particular groups (Electronic Commerce Task Force, 1996:130-5). ${ }^{3}$ For example, comprehensive reviews of 15 Commonwealth Acts regulating the financial sector are to occur over the next four years, in accordance with the legislation review requirements of National Competition Policy. The most significant review is the Financial Systems (Wallis) Inquiry (1996), which reported to the government in March 1997 (Financial Systems Inquiry, 1997). The terms of reference required the review to:

... ensure that financial system providers are well placed to develop technology, services and markets and that the financial system regulatory regime is adaptable to such innovation ... (Commonwealth Treasurer, 1996)

The Final Report of the Financial System Inquiry concluded that a purely reactive approach towards Internet regulation could inhibit the growth of electronic commerce, as many regulatory impediments to e-cash exist, such as uncertainty about the legal status of innovations like digital signatures. It recommended the removal of legislative impediments to electronic commerce, arguing that regulation should not differ between different technologies and should not favour particular types of technology or delivery system. It suggested liberalising access to clearing systems, and argued that Australia should adopt internationally recognised standards for electronic commerce. It concluded that electronic commerce should be

\footnotetext{
${ }^{3}$ This report lists 19 electronic commerce reviews. In addition, the Human Rights and Equal Opportunity Commission monitors the privacy implications of e-cash. The Corporate Law Economic Reform Program announced by the Treasurer in March 1997 will also consider developments in electronic commerce.
} 
subject to regulation to ensure the safety and integrity of the payments system. It noted that a large number of regulatory and legislative changes will be required in Australia simply to allow for electronic commerce (Financial Systems Inquiry, 1997:56-64).

Moves are currently under way to remove regulatory impediments and remedy the absence of common standards. In particular, Standards Australia - a private sector accreditation organisation - has already issued a report recommending the creation of appropriate infrastructure to use a digital signature system (Financial Systems Inquiry 1996:59). In addition, amendments to legislation including Evidence Acts, to accommodate electronic commerce, are likely to be introduced into the parliament by the end of 1997.

Since e-cash can be stored on computers and transferred through e-mail systems, it may totally bypass the existing banking and financial system and the regulations requiring compulsory disclosure to the Australian Transactions Reports and Analysis Centre (AUSTRAC) of large financial transfers by specified financial institutions. The forthcoming 1998-99 Commonwealth review of the Financial Transactions Reports Act 1988 is likely to address this issue. In the interim, the Flectronic Commerce Task Force (1996) prepared a report for the Commonwealth Law Enforcement Board dealing with the implications of electronic commerce for money laundering and other regulations. It assessed the technical and legal features of 'cyberpayments' systems; identified emerging law enforcement issues associated with cyberpayments; and assessed the adequacy of existing laws to regulate cyberpayments.

The Australian Tax Office (ATO) is also concerned about the potential loss of revenue which may arise from electronic commerce though the Internet. It has launched an 'Internet and Electronic Cash Project', which seeks to examine the efficacy of the existing tax structure in the light of innovations in e-cash. Specific issues to be considered include the capacity of existing tax law and administration to deal with money laundering, tax evasion and income non-disclosure, when undertaken through the Internet; the potential erosion of the tax base from commercial use of the Internet; and the extent to which compliance with tax laws may be promoted through organisations involved in Internet commerce, such as Internet Service Providers (ATO, 1997).

The Australian Competition and Consumer Commission (ACCC) has recently established a research program into the implications of electronic commerce for consumer protection. It will examine the difficulties in tracing offenders through the Internet and the jurisdictional problems which arise from the borderless nature of the Internet. It is also developing a code of conduct for on-line shopping (ACCC, 1996:93, 96).

The Australian Securities Commission (ASC) has been extending regulations to electronic commerce. It has established on-line information systems and has released several policy documents. Most notable of these is the recent policy of allowing the use of electronic prospectuses in the financial services industry. This is consistent with the attempts of the ASC to adapt to the changing technology which 
is part of the Internet: 'it is important to identify principles that will help business but ensure confidence in an electronic marketplace' (ASC, 1996:34). The ASC is also working with the International Organisation of Securities Commissions to enhance its enforcement activity (ASC, 1997), and in February 1997 it helped organise a conference on electronic commerce.

Even regulatory organisations whose primary role is not to regulate e-cash are developing regulatory proposals which could impact on e-cash. For example, the Australian Broadcasting Authority (1996) reported to the Commonwealth government on 30 June 1996 on the regulation of on-line services and has proposed selfregulatory codes of practice for Internet service providers. Such codes can encompass a variety of regulatory issues, including electronic commerce. ${ }^{4}$ Further, the Copyright Law Review Committee (CLRC), which is to report on ways to simplify and improve the design of the Copyright Act 1968 by 30 June 1998, is considering issues arising from the increasing use of the Internet. Its terms of reference require that 'In undertaking the inquiry, the CLRC will have regard to technological developments ...' (CLRC, 1997). The CLRC review has implications for electronic commerce, as many products can be transmitted electronically through the Internet - such as pictures and sound - and paid for by e-cash.

\section{Appropriate Regulatory Responses to E-cash}

According to the Financial Systems Inquiry (1997:7), 'Global retail electronic financial transactions are likely to emerge in the near future and will almost certainly flourish over the period to 2010 if the regulatory environment is accommodating'. The development of an appropriate regulatory environment can be assisted through the use of a Regulation Impact Statement (RIS) framework in reviewing existing and new regulation (Industry Commission, 1995, 1996). This approach can significantly enhance the quality of regulation reviews by utilising an analytical framework that seeks to establish a clear rationale and goal for regulation; identification of alternative ways to achieve such goals; an analysis of the impact, costs and benefits of each alternative; transparent consultation processes; and a clear recommendation for an appropriate regulatory response, including processes for the sunsetting or future review of regulation. The Financial Systems Inquiry and other reviews of existing legislation are obliged, under the Competition Principles Agreement between the Commonwealth, States and territories, to employ a RIS framework.

Yet, while some reviews and regulators, such as the ASC, appear to have strong links with international organisations, there is a lack of coordination of reviews within Australia. With the exception of the Financial Systems Inquiry, existing reviews, like that conducted by the ATO, have narrow terms of reference and focus. The Council of Financial Supervisors, which is the main coordinating body for financial sector regulators, does not include among its members important regulators currently assessing e-cash, such as the ATO, AUSTRAC and the ACCC.

\footnotetext{
${ }^{4}$ See Senate Select Committee on Community Standards Relevant to the Supply of Services Utilising Electronic Technologies (1995) for discussion of regulation of on-line services.
} 
There is a need in Australia for a whole-of-government response, similar to the response of the US Presidential task force, to bring together each of the separate ecash reviews and ensure that any regulatory response by governments is well informed, transparent and coordinated. Indeed, in recent months both the Electronic Commerce Task Force (1996) and the President of the Australian Law Reform Commission (1997) have called for improved coordination and cooperation between the large number of Australian e-cash reviews. Clearly, without better coordination there is a greater risk that, as existing regulatory impediments to e-cash are removed, new and unnecessary regulatory impediments to e-cash will be introduced by governments.

\section{Conclusion}

The development and use of electronic commerce, including privately issued ecash, will depend on the pace and development of technological change, its acceptance by consumers and businesses, and the responses of government regulators in Australia and overseas.

According to the Bank for International Settlements (1996), the overall impact of e-cash is likely to be modest, unless its use represents a significant proportion of total economic activity. However, e-cash is likely to result in significant changes in the way economies operate. The value of global transactions over the Internet is estimated to reach US $\$ 600$ billion by 2000 , and US $\$ 1,250$ billion by 2006 (Financial Systems Inquiry, 1996:85).

Governments have incentives to retain their monopoly over the issuing of currency, chiefly to ensure stability of the financial system, while they also benefit from additional revenues from seigniorage and, in some cases, inflation. They also have incentives to reform regulations to encourage the use of e-money, while also ensuring that it does not have unintended consequences such as undermining the tax base. However, poorly designed regulatory responses by governments could unnecessarily impede the use of e-cash, resulting in the loss of economic activity in the financial, retailing and other sectors, and a loss of tax revenues to countries with better regulatory environments.

\section{References}

Australian Broadcasting Authority (1996), 'Investigation into the Content of On-line Services', Report to the Minister for Communications and the Arts, Sydney (30 June).

Australian Competition and Consumer Commission (ACCC) (1996), Annual Report 1995-96, AGPS, Canberra.

Australian Securities Commission (ASC) (1996), Honesty and Faimess in Business: Annual Report 1995/96, Financial and Corporate Relations Pty Ltd, Sydney.

— (1997), home page at http://www.asc.gov.au

Australian Tax Office (ATO) (1997), 'Internet and electronic cash project' at http://www.webaustralia. com.au/ato/ecash/ecashl.htm 
Bank for International Settlements (1996), Implications for Central Banks of the Development of Electronic Money, Basle.

Blinder, A. (1995), Statement before the Subcommittee on Domestic and International Monetary Policy of the Committee on Banking and Financial Services, US House of Representatives, Washington DC (11 October).

Commonwealth Treasurer (1996), 'Financial systems inquiry: terms of reference and membership', Press Release No. 19, Canberra (30 May).

Copyright Law Review Committee (CLRC) (1997), Simplification of the Fair Dealing Provisions of the Copyright Act 1968, Office of Legal Information and Publishing, Attorney-General's Legal Practice, Canberra.

Electronic Commerce Task Force (1996), Report of the Elcctronic Commerce Task Force to the Commonwealth Law Enforcement Board, Australian Transaction Reports and Analysis Centre, Sydney (November).

Financial Systems Inquiry (1996), Financial Systems Inquiry Discussion Paper, AGPS, Canberra (November).

- (1997), Final Report, AGPS, Canberra (March).

Goldschlager, L. \& I. Harper (1996), 'A proposal for a new monetary system to support financial transactions on the Internet', paper delivered at the conference of the Monetary Systems Engineering Group, Department of Computer Science, University of Newcastle, Newcastle (26 March).

Harper, I. \& P. Leslie (1995), 'Electronic Payments Systems and their Economic Implications', Policy 11(1): $23-8$.

Industry Commission (1995), Regulation and its Review 1994-95, Canberra (Appendices A, D and E).

_- (1996), Regulation and its Review 1995-96, Canberra (Chapters 2 and 3, Appendix G).

Kirchner, S. (1996), “'Digital What?”: Electronic Money and the Future of Australia's Financial System', Agenda 3(4): 523-8.

Levy, S. (1995), 'The End of Money?', Newsweek, 30 October: 64-8.

— (1996), 'E-Money (That's what I want)' at http://www.hotwired.com/...12/ features/emoney.html

Lindley, R. (1996), 'Smart Card Risk Assessment (RA): A Preliminary Investigation of the Risk Assessment Needs of Smart Card Technology', paper delivered at the conference of the Monetary Systems Engineering Group, Department of Computer Science, University of Newcastle, Newcastle (26 March).

President of the Australian Law Reform Commission (1997), 'Electronic Commerce and the Law Free Zone: The Limitations of the Law', Speech to the Australian Securities Commission Conference 'Regulating the Marketplace', Sydney (4-5 February).

Senate Select Committee on Community Standards Relevant to the Supply of Services Utilising Electronic Technologies (1995), Report on Regulation of Compute On-Line Services, Part 1, AGPS, Canberra (September). 